Article

\title{
Unexpected corporate outcomes from hedge fund activism in Japan
}

\section{John Buchanan, Dominic H. Chai* and Simon Deakin}

Centre for Business Research, Cambridge Judge Business School, University of Cambridge, Trumpington Street, Cambridge, CB2 1AG, UK

*Correspondence: dhc24@cam.ac.uk

\begin{abstract}
Hedge fund activism has been identified in the USA as a driver of enduring corporate governance change and market perception. We investigate this claim in an empirical study to see whether activism produced similar results in Japan in four representative areas: management effectiveness, managerial decisions, labour management and market perception. Experience from the USA would predict positive changes at Japanese target companies in these four areas. However, analysis of financial data shows that no enduring changes were apparent in the first three areas, and that market perception was consistently unfavourable. Our findings demonstrate that the same pressures need not produce the same results in different markets. Moreover, while the effects of the global financial crisis should not be ignored, we conclude that the country-level differences in corporate governance identified in the varieties of capitalism literature are robust, at least in the short term.
\end{abstract}

Key words: Corporate governance, Japan, institutions, finance

JEL classification: G23, K22, P52

\section{Introduction}

Hedge fund activism is essentially a search for investment returns through pressure on firms to change their corporate governance. Beginning in the USA in the 1980s, it spread to Europe and Asia in the following decades and is increasingly seen as a global phenomenon (Becht et al., 2015). Seen by its critics as a form of 'extortion' (Lipton, 2013), hedge fund activism has nevertheless found support from a series of empirical papers identifying positive impacts of interventions on the performance of target companies (Brav et al., 2008, 2015; Bebchuk et al., 2015; Becht et al., 2015).

In this article, we investigate whether activist hedge fund interventions in Japan produced similarly positive, enduring outcomes to interventions in the USA in terms of financial 
indicators chosen to represent the four areas of management effectiveness, managerial decisions, labour management and market perceptions. In order to achieve this, we employ data on 117 Japanese companies targeted by 17 hedge funds considered to have a broadly defined activist agenda at the end of 2007 and compare them to peer groups at three stages: immediately prior to 2007 (as a basic calibration), and then at one and three years after 2007 to observe divergence. We then consider whether the outcomes we find reflect experience from the USA over similar timescales.

Our research question is therefore whether the tactic of activism refined in one national market produced similar results for corporate governance and market perception in another national market with similar corporate structures and legislation. We answer this question and then offer suggestions, drawing on the concept of 'institutional distance', on why the situation we have identified may have emerged.

We define the background to this study by describing the activist hedge funds and the operating methods they developed in the USA, and by reviewing the conclusions of researchers there on the outcomes they produced. We consider the intellectual underpinning of hedge fund activism in agency theory, observing its roots in the American market context and its wide acceptance there as orthodoxy. Then we look at the Japanese market and summarize its historical environment, noting its significance divergence from the USA, especially in its focus on the concept of 'corporate value' rather than on shareholder value. To demonstrate the results of this divergence, we observe the experience of two particularly aggressive activist hedge funds which entered the Japanese market from the early 2000s employing tactics similar to those employed successfully in the USA and elsewhere, whose interventions comprise 30 of the total of 117 in our sample.

Against this background we present the findings of our quantitative research into the performance of the full sample of 117 companies selected. We first explain our methodology for company and peer group selection, and then present the results of our study. We discuss the implications of these results, first in the context of Japan and then in the wider context of corporate governance in general, and consider the possibility of convergence on US practice that has been predicted by some commentators. Finally, we offer our conclusions, which point to the continuing relevance of the cross-national divergences identified in the varieties of capitalism literature (Hall and Soskice, 2001), at least in the medium term.

\subsection{Activist hedge funds and their US environment}

We define activist hedge funds as those which research targets to identify latent value and then acquire minority shareholdings as footholds to press boards to initiate changes in corporate governance in order to release that value (please note also our working definition in the 'Methodology' section below). Like hedge funds in general (Kellard et al., 2017) they seek returns for their investors but, unlike other hedge funds, they focus explicitly on perceived inefficiencies in their targets' structures or strategies, such as inefficient use of assets or failure to realize commercial opportunities, which generally have corporate governance implications. As Bratton describes them: 'They look for value but want it realized in the near or intermediate term. Their strategy is to tell managers how to realize the value and to challenge publicly those who resist their advice' (Bratton, 2007, p. 1383). The distinction between activists and more patient value investors is sometimes vague because both seek value through improved corporate efficiency and both may be categorized as 'activists' 
whenever they engage with companies. A recent Preqin report estimated total assets under management by 'activists' (which it defines as 'hedge funds using shareholder activism as a method of investment') to be more than US $\$ 100,000$ (Preqin, 2014). This amounts to less than $0.4 \%$ of the OECD's estimate of total institutional investment assets using data from a majority of its member countries, mostly from 2009 (OECD, 2009). However, despite the relatively small volume of assets controlled by such funds in a global context, they often have a major impact: a comparative study of the effect on employment of investments by private equity, a hedge fund and a sovereign wealth fund (though from a small sample) found that the hedge fund intervention, with the lowest shareholding of the three, had the greatest impact (Gospel et al., 2011). Moreover, the often public and confrontational nature of their interventions has given them a disproportionately high profile; during 2007 Japan's leading financial newspaper, Nihon Keizai Shimbun, alone carried nearly 500 articles on investments by activists or value funds in Japan (Buchanan et al., 2012, p. 173).

In the USA, the market where activist hedge funds made their first appearances during the 1990s and where much of the research into their operations has been conducted, they are often viewed as a force for good corporate governance. Some commentators have seen the governance implications of their quest for returns as a vital means to promote shareholder value, in contrast to the disappointing achievements of more traditional institutional shareholders such as pension funds, and in this context they have been described as 'the great, shining beacon of hope' for improved corporate governance (Macey, 2008, p. 272). Brav, Jiang, Partnoy and Thomas, in their study of over 1,000 US activist interventions from 2001 to 2006, conclude that their 'informed shareholder monitoring can reduce agency costs at targeted firms' (Brav et al., 2008, pp. 1772-1773).

These conclusions are not unanimously supported and other research suggests negative aspects. Klein and Zur observe deterioration in the standing of targeted companies' bonds, while $\mathrm{Li}$ and $\mathrm{Xu}$ find that banks view their credit risk more harshly as resources are diverted from companies' businesses to their shareholders (Klein and Zur, 2011, pp. 1735-1736; Li and $\mathrm{Xu}, 2009$, p. 25). Nevertheless, recent analysis of the effects of hedge fund activism in the USA has pointed to improvements in the way that companies perform, driven by changes in the ways that they are managed, and also to reductions in labour's share of the returns with a corresponding increase going to investors in the form of dividends and share buybacks. All of these are considered to be fundamentally healthy outcomes which are welcomed by investors. For example, Brav, Jiang and Kim see hedge fund activists as a means to mitigate the influence of 'entrenched labour' because they 'prefer intense monitoring to generous wages, improving the productivity and profitability of target firms'. They consider that targeted companies usually have poor productivity before intervention, which tends to be 'reversed within the 2- to 3-year period post targeting'. Effectively the operating structure of the targeted companies changes, with employees delivering greater productivity but losing out to investors: 'The improvement in labor productivity coupled with relatively stable wages indicates that workers do not fully capture the value of productivity improvements, but instead relinquish most of the surplus to equity investors after hedge fund intervention' (Brav et al, 2015, p. 2726).

But perhaps the most positive impression regarding hedge fund activism in the USA is that it creates enduring improvements in targeted companies' performance and is favourably received longer term by the market, implying consistently higher share prices. Brav, Jiang, Partnoy and Thomas find that announcements of interventions generated a positive market 
response which persisted one year later. Looking particularly at confrontational activism, they conclude that 'the more favorable market response indicates that the perceived value improvement comes from imposed changes, rather than a mere discovery of undervaluation due to mispricing .... The positive market reaction to hedge fund intervention that we find is consistent with the improved post-intervention target performance ...' (Brav et al., 2008, pp. 1764 and 1773). In contrast, Klein and Zur, using a sample of 151 interventions between 2003 and 2005, find an initial deterioration in target companies' financial positions, which corroborates the deterioration in bond and credit perceptions mentioned above, and no improvement in the second year after intervention, although this finding is based on only part of their full sample (Klein and Zur, 2009, p. 225). However, this view of only shortterm benefits has recently been contested by Bebchuk, Brav and Jiang. They examine 2,040 interventions between 1994 and 2007, using data on operating performance and stock returns for the extended period 1991-2012, and conclude that during the third, fourth and fifth years after intervention not only does operating performance generally show no decline, but an improvement is evident in Tobin's Q: 'We find no evidence that such interventions ... involve "sacrificing the future for a quick buck"'(Bebchuk et al, 2015, pp. 1090 and 1141).

Underlying the interventions of activist hedge funds in the USA is the path-dependent history of the US market. By the early 1930s, as Berle and Means observed, growing dispersion of shareholdings at large companies was releasing management from shareholder control (Berle and Means, 1932). Subsequently, this new managerial autonomy was challenged as institutional investors such as pension funds, mutual funds and insurers became important shareholders. From a low base in the 1940s, they progressively increased their shareholdings in the largest 1,000 US companies to reach $46.6 \%$ in 1987 and $76.4 \%$ by late 2007 (Conference Board, 2008), creating a network of more concentrated portfolio shareholders willing and able to promote their interests. Scandals in the 1970s, such as the Penn Central bankruptcy, drew attention to the dangers of unsupervised executive power and strengthened the case for supervising and controlling management more effectively (Cadbury, 2002, pp. 7-8).

A theoretical framework emerged to complement and justify this process. 'Agency theory' explained the tendency for management to arrogate power and wealth from the true 'owners' of the company, its shareholders, and posited a need to find remedies. Jensen and Meckling's 'Theory of the firm' paper (1976) explained the firm as a nexus of contracts rather than as a legal person with independent existence, where owners, in the form of shareholders, sought to reduce agency costs by controlling their agents, in the form of managers, who would otherwise be predisposed to act in their own self-interest at the expense of total firm value (Jensen and Meckling, 1976). Jensen expanded this argument to focus on the need to supervise these agents, especially where the business generated free cash flow that management might be tempted to squander: 'Conflicts of interest between shareholders and managers over payout policies are especially severe when the organization generates substantial free cash flow. The problem is how to motivate managers to disgorge the cash rather than investing it at below the cost of capital or wasting it on organization inefficiencies' (Jensen, 1986, p. 323). By 1990s, these trends had produced a widespread view that companies existed primarily for the benefit of their shareholders and that the duty of management was to promote 'shareholder value'. By 2004, it could be stated that 'In the field of finance, the logic of shareholder value maximization is accepted as being so obvious that textbooks just assert it, rather than argue for it. Deviation from this objective is cast as an agency 
problem resulting from the separation of ownership and control, and failure to meet this goal is assumed to be corrected by corporate boards, shareholder voice, shareholder exit, and the market for corporate control' (Sundaram and Inkpen, 2004, p. 350). This idea began to achieve recognition outside the USA, encouraging belief in a process of inevitable global convergence: 'There is no longer any serious competitor to the view that corporate law should principally strive to increase long-term shareholder value. This emergent consensus has already profoundly affected corporate governance practices throughout the world' (Hansmann and Kraakman, 2001, p. 439).

This was the background to the emergence of hedge fund activism in the USA in the 1990s, where the quest for shareholder value had become accepted by both investors and corporate boards as the correct way to run a company, even though there might be differences of opinion over the details and timing of its implementation. The funds were able to target boards that appeared to have neglected this orthodoxy, secure in the knowledge that the fundamental principle of shareholder value was difficult to challenge (Strine, 2016).

\subsection{The spread of activism and the changing corporate governance environment in Japan}

From 2000, activist hedge funds, both Japanese and foreign, began to apply methods similar to those developed in the USA to the Japanese market. Their demands covered a wide spectrum: Steel Partners tended to demand increased dividends from cash-rich targets, Dalton concentrated on MBO proposals to release value, and TCI focused on large companies whose complexity might benefit from simplification and thereby release cash or generate disposal opportunities. Their underlying argument was that the post-War Japanese model of companies, which was focused only on corporate value and therefore more inclined to accumulate cash rather than distribute it, was unacceptable in an age of shareholder value. They generally sought early release of cash to shareholders either by reducing reserves or by redirecting strategy from expensive longer-term objectives. In the Japanese context they were 'insurrectionaries' who actively mobilized against the institutional status quo (Mahoney and Thelen, 2010, p. 23).

Their interventions in Japanese target companies have not been as extensive as their US operations, nor have their experiences in Japan been as closely examined as in the USA. The funds themselves began to operate in Japan because they saw opportunity there but, by the end of 2008, it was evident that interventions using public and confrontational methods were increasingly unproductive. The winding down of this hedge fund activism in Japan was accelerated by the global financial crisis and the pressure it put on funds to maintain their liquidity from 2008, but other factors, specific to the Japanese market and institutional context, were also at work. This is illustrated by the experience of two funds which attracted great attention in the Japanese press for their perceived willingness to confront target boards: The Children's Investment Fund ('TCI') of the UK and Steel Partners of the USA (operating through their joint venture with Liberty Square). In October 2008, TCI withdrew from a protracted and increasingly vituperative intervention in the electrical utility J-Power, apparently at a loss (FT, 2008). In January 2009, despite previous success in extracting accumulated cash from several small listed companies, it was reported that Steel Partners had sold in full or reduced their holdings in 13 Japanese targets, amid speculation that they had overexposed themselves (Reuters, 2009). TCI continued its involvement in Japan thereafter with a 
much lower profile, and in December 2014 Steel Partners appeared largely to have withdrawn from their only remaining major Japanese investment, in the wigmaker Aderans, an intervention that began in 2004 and seems unlikely to have delivered a good return. There were clearly factors present in the Japanese market that differentiated it from the USA.

At the root of these factors is a different conception of the purpose of the firm that evolved in Japan following the Second World War. The corporate model that emerged was forged by the demands of the labour force to be recognized as a stakeholder in the enterprise to which it contributed its efforts, an acceptance by management that a degree of concession was the only solution to the disruptive industrial action that characterized the late 1940s and early 1950s at many large Japanese companies and, most importantly, a general understanding that cooperation for the benefit of the business was the only way to prevent corporate collapse and personal destitution in the hard years immediately after the war. As Gordon describes it in his account of the Japanese steel industry: 'The good of the company was the good of all its members and of society at large. The interests of workers and managers, of labor and capital, were in basic accord' (Gordon, 1998, p. 201).

The resulting balance of forces created the 'community firm' in which, although hierarchical distinctions certainly exist, the employees at all levels identify strongly with the company as a continuing business to which they are personally committed. This model is indeed a 'nexus of contracts' but one where the company is perceived to be of value in itself, and it has proved robust. In 2006, Mitarai Fujio and Niwa Uichirō, then chairmen of Canon and Itochū respectively, published a book of commentaries on the purpose of the company entitled Kaisha wa dare no tame ni ('Who is the company for?'). Mitarai wrote: 'When one talks about things like a "spirit of love for one's company" it may be dismissed by many people as old-fashioned but it is something that I personally want to emphasize at this time particularly. I want management, for a start, and every single employee to have this feeling of love for the company' (Mitarai and Niwa, 2006, p. 100). Underlying this attitude to the company is a stable employment structure, at least for permanent employees at large Japanese companies, whereby school-leavers or university graduates may expect to join a company for the entirety of their working lives and rise within that organization over time. Thus Japanese senior managers have been described as the winners of a fierce competition for internal promotion who run the business for the sake of the whole body of employees (Tachibanaki, 1998, p. 249), rather than to promote shareholder value through disbursement of profits.

The stable employment model is currently under pressure from the rise of atypical labour (Sako, 2005, p. 591): according to official figures, approximately $20 \%$ of the male labour force was employed on short-term contracts of various kinds at the beginning of 2013, compared to less than $8 \%$ in 1984 (MIC, 2013). A gradual process is also evident in Japan whereby the necessity for a greater allocation of wealth to the investment and pensions sector is driving demand for a rise in corporate dividends: Thomson Reuters data show a mostly steady rise in dividends as percentages of sales and assets for companies listed on the Tokyo and Osaka markets from 2003, with a fall in 2009-2010 before growth resumed. The growing influence of foreign institutional investors in Japan, which can be traced back to the 1990s and has been steadily increasing since (Ahmadjian and Robbins, 2001), is partly responsible for this: overseas ownership is correlated with the unwinding of cross-shareholdings which served to insulate managers in the past from stock market pressures, and with an increased incidence of restructurings, which have further contributed to the erosion of the lifetime employment model (Ahmadjian and Robbins, 2005; Ahmadjian, 2007). However, the focus on the firm as 
a community of shared interests remains intact: as Tiberghien observes in a study of Japanese capitalism which develops the premise that change has been in progress for the past 30 years, 'the model that results from this process is less coherent than in 1980, partly modified, partly resilient' (Tiberghien, 2014, p. 52). Moreover, as Lechevalier emphasizes in the same study, 'it has been profoundly changed, though this certainly does not mean convergence towards Anglo-Saxon or European forms of capitalism' (Lechevalier, 2014, p. 2). Miyajima (2017, p. 7) suggests that the impact of the 2008 financial crisis on attitudes to corporate governance in Japan was, if anything, to call into question the move to a more liberalized and financialized economy that had characterized the preceding decade: 'the emergence of the sub-prime crisis from the summer of 2007 and the Lehman Shock of September the following year brought about a decisive change whereby doubts suddenly intensified regarding the trend towards a market economy along American lines that had continued unabated since 1997’.

Differences in adoption of corporate governance theory between the USA and Japan are also important. As we have seen, agency theory ideas penetrated the financial and business world in the USA to encourage an orthodoxy of shareholder value maximization. In Japan, although admiration for the contemporary success of the US economy and the belief that this success was driven by American corporate governance structures created enthusiasm for introduction of these practices from the 1990s, this was more a search for practical solutions to perceived problems in the aftermath of the equity and real estate Bubble than a reasoned examination of theories. The ideas which emerged elsewhere to confront agency theory's implicit prioritization of shareholder value, such as 'stakeholder theory', 'stewardship theory' and 'team production theory' (for example: Kay and Silberston, 1995; Davis et al, 1997; Blair and Stout, 1999) were already accepted tacitly in Japan as normal corporate governance and management tended to reject shareholder value ideas as a threat to the cohesion of their companies (Jackson, 2003).

\section{Methodology}

We have explained the background to hedge fund activism in Japan during the period 20002008, noting firstly that two confrontational funds which attracted public attention did not succeed in generating consistently high returns from their interventions, and secondly that they faced a corporate governance environment which prioritized corporate value over shareholder value. We now turn to our research question: whether the tactic of activism refined in one national market (the USA) produced similar results for corporate governance and market perception in another national market with similar corporate structures and legislation (Japan). To do this, we carried out a quantitative survey of all the relevant Japanese companies that we could identify as targets of hedge fund activism and for which suitable data were available as at the end of 2007, the year that was with hindsight the high point of hedge fund activism in Japan (Buchanan et al, 2012), and compared them to a sample of peer group companies in order to determine their comparative performance on our criteria in the years following the interventions. Our working definition of 'activism' for this purpose is any form of prescriptive engagement, which therefore encompasses a broad group of investors between the two extremes of confrontational funds and more circumspect funds, some of which might describe themselves as 'value funds'.

Our chosen benchmark for comparison is the US market where activist hedge funds are most numerous and where their activities have been studied in the greatest depth, providing 
us with an effective template to which we can compare our Japanese results. In the USA, the broad consensus (although not accepted by all) is that activist hedge funds generate change, and that the stock market tends to react favourably in the sense that share prices of target companies rise from the stage of intervention, apparently with little sensitivity to the actual remedies proposed by the funds or the period for which they continue to be shareholders. It has further been argued, by Bebchuk et al. (2015), that beneficial changes persist several years after the interventions into the medium term. In order to achieve a robust comparison with these data, we have used a methodology similar to that used by Brav et al. (2008) and Klein and Zur (2009) in their main US studies.

We began with Thomson Reuters' database of investments by entities described as 'hedge funds' with 'active orientation' as at December 2007. This is a very loose definition but it provided an initial list of 145 interventions in individual non-financial companies listed in Tokyo and Osaka. We removed from this list 80 companies where we were unsure that activism, even under our own broad working definition, had really taken place or where we felt unable to conduct suitable analysis. These comprised asset management vehicles (since we consider that they offered little scope for structural or strategic change), companies which subsequently delisted (making financial comparisons difficult) and companies where the fund in question had declared general policies through the press or its own website that suggested that it did not practice activism.

By these means we arrived at a list of 65 companies from the Thomson Reuters database of 145 , all of which are still listed, and which we considered to have been likely activist targets in view of the funds involved. To these we added a further 52 companies, also still listed, which did not feature in the Thomson Reuters data but which we had identified as targets from our primary research and press searches, to give a total of 117 companies in which 17 funds were investing at the end of 2007. These funds are listed in Appendix 1. We believe that some of these funds would contest the description 'activist' and, from our own research, consider some to be more accurately 'value' investors which normally adopt a less confrontational attitude to their targets; we justify their inclusion here because of the need to include interventions where pressure was applied in private.

We then match each target company with a group of other companies which are comparable to it with reference to industry, total book asset value and book-to-market ratio. There are three stages in this process. First, we employ a matching algorithm to identify all companies with the same two-digit industry classification in Japan. Secondly, we select the 10 closest companies in terms of total assets to each target. Then, from these 10 possible matches, we choose the 5 companies with the closest book-to-market ratio to each target and calculate the average for each group of 5 to create our matched samples.

We first calibrate our process by comparing the target companies to each appropriate matched sample as at 2007 (generally using March 2006 data to represent the information available immediately prior to 2007). This allows us to form a view on what the activists were seeking in their targets. Then we compare the target companies to their respective matched samples, firstly at one year after the interventions we have observed in 2007 (comparing 2008 to 2007 results) and then at 3 years from 2007 (comparing 2010 to 2007 results). We analyse the potential areas for change under our four categories of 'management effectiveness', 'management decisions', 'labour management' and 'market perception'. These four categories are all examined under multiple criteria in order to increase the robustness of our analysis, as follows: return on assets and return on equity to demonstrate management 
effectiveness; ratio of dividend to total assets, leverage, ratio of cash to total assets and ratio of capital expenditure to total assets to demonstrate changes in managerial decisions; ratio of sales to employees to express labour productivity; ratio of wages to sales to express wage intensity and the log of market capitalization and Tobin's Q to demonstrate shifts in market perception. Our variables are described in more detail in Appendix 2.

Although the boards of Japanese companies targeted in interventions by the two aggressive funds described above publicly opposed the activists, it is still possible that they were forced to change their governance practices under the public pressure to which they were subjected by these funds. Moreover, the full sample of 117 companies that we use for our quantitative analysis also includes companies subjected to more subtle pressure from funds who kept their discussions private, who may have had greater success outside the public eye. Whether the changes were driven by aggressive activism or more private persuasion, investors would surely benefit from a shift to greater emphasis on shareholder value and therefore it seems likely that the market would view results produced by these interventions favourably. Interestingly, in the German market, where similarities to Japan have been observed - for example, by Dore (2000) — a recent study has noted both the expected ability of blockholders to impede activism and the unexpectedly nuanced outcomes that sometimes result (Fichtner, 2015).

We are constrained in our choice of methodology by our desire to use a similar method to the US studies. Nevertheless, we have varied our approach slightly to increase robustness. Klein and Zur (2009) use one-to-one matching but we have followed Brav et al (2008) in our process of reduction from 10 to 5 comparative companies, differing only in two respects: we use two digit rather than three digit SIC to locate our groups of 10, whereas Brav et (2008) use three initially, dropping to two only where suitable matches are lacking, and we use the average of each five company group rather than selecting a single comparator company from each group, which we consider a more robust approach. A potential weakness of this methodology in general is that the targets may have such distinctive characteristics that no sample offers a true comparison, despite meeting the financial criteria described. However, we are dealing here with 117 targets, which should provide enough breadth to compensate for variations in the results. Moreover, we know in the case of the 52 targets provided through our own research that although they attracted activists for their cash reserves, potential as $\mathrm{MBO}$ candidates or potential for strategic revival, none were unique in the context of the Japanese market.

\section{Results}

The basic characteristics of companies targeted by activist hedge funds are shown in Table 1 . This sets out summary statistics on the target companies and reports the results of the univariate analyses of the differences between the targets and the matched samples as of 2006/7. Columns 1 to 6 report the summary statistics (mean, median and standard deviations) between the targets and their respective sample groups. Column 7 shows the $t$-statistics, which measure differences in means, while column 8 reports $z$-statistics for differences in medians, using a Wilcoxon signed rank test. The Wilcoxon test is less influenced by extreme observations and is included here as a robustness check, given that the skewness of the variables included in the analysis can be expected to affect the analysis of the means. In presenting our results we assume that a difference between the target company and its peers is 
Table 1. Characteristics of target companies

\begin{tabular}{|c|c|c|c|c|c|c|c|c|c|c|}
\hline \multirow[b]{3}{*}{ Firm characteristics } & \multicolumn{6}{|c|}{ Target firms $(N=117)$ Matched firms } & \multicolumn{4}{|c|}{ Difference with matched firms } \\
\hline & \multirow{2}{*}{$\frac{\text { Mean }}{(1)}$} & \multicolumn{2}{|c|}{ Median SD } & \multirow{2}{*}{$\frac{\text { Mean }}{(4)}$} & \multicolumn{2}{|c|}{ Median $S D$} & \multicolumn{2}{|l|}{$t$-Statistics } & \multicolumn{2}{|l|}{ Wilcoxon } \\
\hline & & (2) & (3) & & (5) & (6) & (7) & & (8) & \\
\hline \multicolumn{11}{|l|}{ Management effectiveness } \\
\hline Return on assets & 0.033 & 0.035 & 0.036 & 0.017 & 0.024 & 0.066 & 2.609 & $* *$ & 3.623 & $* * *$ \\
\hline Return on equity & 0.047 & 0.057 & 0.135 & 0.025 & 0.050 & 0.173 & 1.286 & & 1.856 & + \\
\hline \multicolumn{11}{|l|}{ Managerial decisions } \\
\hline Dividend/assets & 0.010 & 0.008 & 0.007 & 0.007 & 0.007 & 0.005 & 4.504 & $* * *$ & 4.232 & $* * *$ \\
\hline Leverage & 0.165 & 0.067 & 0.206 & 0.265 & 0.241 & 0.225 & -4.434 & $* * *$ & -4.765 & $* * *$ \\
\hline Cash/assets & 0.166 & 0.137 & 0.135 & 0.118 & 0.089 & 0.116 & 3.992 & $* * *$ & 3.758 & $* *$ \\
\hline Capital expenditures/assets & s 0.033 & 0.027 & 0.036 & 0.036 & 0.025 & 0.039 & -0.933 & & -0.804 & \\
\hline \multicolumn{11}{|l|}{ Labour management } \\
\hline Labour productivity & 62.922 & 44.573 & 72.133 & 54.142 & 37.5316 & 61.892 & 1.358 & & 1.279 & \\
\hline Wage intensity & 0.176 & 0.138 & 0.124 & 0.181 & 0.158 & 0.142 & -0.405 & & -0.403 & \\
\hline \multicolumn{11}{|l|}{ Market perception } \\
\hline Ln(Market Cap) & 10.307 & 10.129 & 1.288 & 9.894 & 9.702 & 1.325 & 3.084 & $* *$ & 3.160 & $* *$ \\
\hline Tobin's Q & 1.269 & 1.123 & 0.461 & 1.191 & 1.085 & 0.422 & 1.786 & + & 1.671 & + \\
\hline
\end{tabular}

Notes: This table reports the characteristics of target companies and comparisons with a set of matched companies. The first three columns report the mean, median and standard deviation of the characteristics for the target companies. Columns 4 through 6 report the mean, median, and standard deviation of the characteristics for the industry/size/book-to-market matched companies. Column 7 reports the $t$-statistics for the average differences, and column 8 reports the Wilcoxon signed rank statistics, which are asymptotically normal, for the median differences.

${ }^{* * *}$ Significant at the 0.001 level; ** significant at the 0.01 level; * ${ }^{*}$ ignificant at the 0.05 level; ${ }^{+}$significant at the 0.10 level.

statistically significant if both the $t$-statistic and the Wilcoxon test indicate a two-tail significance of at least 5 per cent.

Our results suggest that the targeting strategy of the activist hedge funds in Japan was not identical to that found in the US studies, which were observing a more mature market for activism, but does show important similarities. For example, Klein and Zur note that 'Hedge fund activists target more profitable and financially healthy companies than other entrepreneurial activists' (Klein and Zur, 2009, p. 189). Here we note a superior return on assets compared to the peer companies of the matched samples. However Brav, Jiang, Partnoy and Thomas' summary of target companies' characteristics suggests some differences of approach: "Hedge fund activists tend to target companies that are typically "value" firms, with low market value relative to book value, although they are profitable with sound operating cash flows and return on assets. Payout at these companies before intervention is lower than that of matched firms' (Brav et al., 2008, p. 1730). While some of this description, notably regarding profitability and return on assets, appears to apply equally to these Japanese targets, they seem to have paid higher than average dividends and to have been well regarded by the market in 2006. A defining characteristic in Japan seems to have been cash and the low leverage that this implies: these companies display significantly lower leverage than their peers. A similar phenomenon has been noted in the USA by Bratton: 'Cash 
rich firms show up prominently in the sample' but with a decline over the years of his study period, implying that 'activists grabbed low-hanging fruit in the first three years' (Bratton, 2007, p. 1395), which suggests a parallel with the strategy of activist hedge funds in Japan as they approached a new market and were drawn first to cash-rich targets. As a British activist hedge fund director explained to us during interviews carried out in the UK in 2009, it is usually easier to justify demands to hand back accumulated cash to investors than to enter a strategic discussion where subjective views inevitably come into play. With regard to labour management, the targeted companies do not show signs of the initially poor productivity that Brav et al (2015) identified at many American targets. Labour productivity appears to be superior and wage intensity lower than at the matched samples, although not to a statistically significant degree.

Tables 2 and 3 summarize one-year and three-year changes in firm characteristics for firms targeted by activist hedge funds. The first three columns report the mean, median and standard deviation of the 3-year characteristics changes for the target companies. Column 4 reports the average difference of one-year or three-year changes between the sample firms and the industry/size/book-to-market matched firms. Difference is taken between the target company and the average of the matching firms and then averaged over all target companies. Column 5 reports the $\mathrm{t}$-statistics for these average differences.

Table 2. One-year changes in target firm performance

\begin{tabular}{|c|c|c|c|c|c|c|}
\hline \multirow[b]{3}{*}{ Firm characteristics } & \multicolumn{3}{|c|}{ Summary statistics $(t+1)-(t)$} & \multicolumn{3}{|c|}{ Difference with matched firms } \\
\hline & \multirow{2}{*}{$\frac{\text { Mean }}{(1)}$} & \multirow{2}{*}{$\frac{\text { Median }}{(2)}$} & \multirow{2}{*}{$\frac{S D}{(3)}$} & \multirow{2}{*}{$\frac{\text { Diff w/Match }}{(4)}$} & \multicolumn{2}{|l|}{$t$-statistic } \\
\hline & & & & & (5) & \\
\hline \multicolumn{7}{|c|}{ Changes in management effectiveness } \\
\hline$\Delta$ Return on assets & -0.011 & -0.005 & 0.033 & -0.005 & -1.480 & \\
\hline$\Delta$ Return on equity & -0.022 & -0.010 & 0.115 & -0.002 & -0.061 & \\
\hline \multicolumn{7}{|l|}{ Changes in managerial decisions } \\
\hline$\Delta$ Dividend/assets & 0.002 & 0.001 & 0.004 & 0.001 & 3.445 & $* * *$ \\
\hline$\Delta$ Leverage & 0.006 & 0.000 & 0.046 & 0.008 & 2.080 & $*$ \\
\hline$\Delta$ Cash/assets & 0.005 & 0.000 & 0.043 & 0.004 & 1.543 & \\
\hline$\Delta$ Capital expenditures/assets & -0.001 & 0.001 & 0.026 & 0.000 & -0.404 & \\
\hline \multicolumn{7}{|l|}{ Labour management } \\
\hline$\Delta$ Labour productivity & -0.741 & -0.421 & 8.007 & -0.926 & -1.169 & \\
\hline$\Delta$ Wage intensity & 0.005 & 0.002 & 0.019 & 0.001 & 0.869 & \\
\hline \multicolumn{7}{|l|}{ Changes in market perception } \\
\hline$\Delta \operatorname{Ln}($ Market Cap) & -0.381 & -0.364 & 0.283 & 0.013 & 0.713 & \\
\hline$\Delta$ Tobin's Q & -0.203 & -0.182 & 0.178 & -0.038 & -3.014 & $* *$ \\
\hline
\end{tabular}

Notes: This table summarizes changes $(\Delta)$ in firm characteristics between the years 2007 and 2008 for firms targeted by activist hedge funds. The first three columns report the mean, median and standard deviation of the one-year characteristics changes for the target companies. Column 4 reports the average difference of 3-year changes between the sample firms and the industry/size/book-to-market matched firms. Difference is taken between the target company and the average of the matching firms and then averaged over all target companies ('Diff w/Match'). Column 5 reports the t-statistics for the average differences.

***Significant at the 0.001 level; **significant at the 0.01 level; *significant at the 0.05 level. 
Table 3. Three-year changes in target firm performance

\begin{tabular}{|c|c|c|c|c|c|c|}
\hline \multirow[b]{3}{*}{ Firm characteristics } & \multicolumn{3}{|c|}{ Summary statistics $(t+1)-(t)$} & \multicolumn{3}{|c|}{ Difference with matched firms } \\
\hline & \multirow{2}{*}{$\frac{\text { Mean }}{(1)}$} & \multirow{2}{*}{$\frac{\text { Median }}{(2)}$} & \multirow{2}{*}{$\frac{S D}{(3)}$} & \multirow{2}{*}{$\frac{\text { Diff w/Match }}{(4)}$} & \multicolumn{2}{|l|}{$t$-statistic } \\
\hline & & & & & $(5)$ & \\
\hline \multicolumn{7}{|c|}{ Changes in management effectiveness } \\
\hline$\Delta$ Return on assets & -0.021 & -0.012 & 0.048 & -0.011 & -2.599 & $* * *$ \\
\hline$\Delta$ Return on equity & -0.053 & -0.024 & 0.186 & -0.066 & -2.501 & * \\
\hline \multicolumn{7}{|c|}{ Changes in managerial decisions } \\
\hline$\Delta$ Dividend/assets & -0.001 & 0.000 & 0.006 & 0.000 & -0.540 & \\
\hline$\Delta$ Leverage & 0.025 & 0.001 & 0.078 & -0.007 & -0.540 & \\
\hline$\Delta$ Cash/assets & 0.022 & 0.021 & 0.071 & -0.007 & -1.161 & \\
\hline$\Delta$ Capital expenditures/assets & -0.012 & -0.004 & 0.034 & 0.000 & -0.139 & \\
\hline \multicolumn{7}{|l|}{ Labour management } \\
\hline$\Delta$ Labour productivity & -8.920 & -4.929 & 18.310 & -0.350 & -0.261 & \\
\hline$\Delta$ Wage intensity & 0.027 & 0.012 & 0.050 & 0.001 & 0.339 & \\
\hline \multicolumn{7}{|l|}{ Changes in market perception } \\
\hline$\Delta \operatorname{Ln}($ Market Cap) & -0.623 & -0.660 & 0.448 & -0.112 & -4.067 & $* * *$ \\
\hline$\Delta$ Tobin's Q & -0.310 & -0.285 & 0.270 & -0.173 & -4.897 & $* * *$ \\
\hline
\end{tabular}

Notes: This table summarizes changes $(\Delta)$ in firm characteristics between the years 2007 and 2010 for firms targeted by activist hedge funds. The first three columns report the mean, median and standard deviation of the three-year characteristics changes for the target companies. Column 4 reports the average difference of threeyear changes between the sample firms and the industry/size/book-to-market matched firms. Difference is taken between the target company and the average of the matching firms and then averaged over all target companies ('Diff w/Match'). Column 5 reports the $t$-statistics for the average differences.

$* * *$ Significant at the 0.001 level; ** significant at the 0.01 level; * significant at the 0.05 level.

Table 2 shows that there was no immediate effect on management effectiveness in 2008, as we have defined it here. The most notable change was in management decisions on dividend policy, where the ratio of dividends to total assets increased significantly, as might be expected from companies under pressure to increase payments to shareholders. Leverage rose slightly, which corroborates a picture of management raising gearing and increasing payout. Labour management issues are in line with the situation at the matched samples, with no significant divergence. However, the reaction of the market, as evidenced by movement in Tobin's Q, was not favourable. This seems contradictory to the prediction of investors welcoming the prospect of continued higher payouts and does not agree with the US experience. It is also surprising, since investors might be expected to buy if companies had been exposed to the arguments of pro-shareholder activists because they would have greater expectations of increased dividends and a higher share price in the future.

Table 3 shows a detrimental change in management effectiveness in 2010: the targeted companies, which in 2006 were strong performers, now slightly underperform the matched samples. In terms of managerial decisions, our chosen indicators are not significantly different from those of the matched samples, and the increase in dividend payments is no longer significant. Labour management issues are again in line with the situation at the matched samples, with no significant divergence. The interventions appear to have had no effect on the targeted companies during the three year period with regard to the structure of their 
Table 4. Summary of results

Expectations from the US experience Similarity in Japan

\begin{tabular}{lll}
\cline { 2 - 3 } & Short term(1 year) & Medium term(3 years) \\
\hline $\begin{array}{l}\text { 1. Improved management effectiveness } \\
\text { (demonstrated by return on assets and return on } \\
\text { equity) }\end{array}$ & No & No \\
$\begin{array}{l}\text { 2. Encouragement to management to revise its } \\
\text { financial strategy (demonstrated by ratio of } \\
\text { dividend to total assets, leverage, ratio of cash to }\end{array}$ & Yes & No \\
total assets, and ratio of capital expenditure to \\
total assets)
\end{tabular}

wages and productivity. The indications of market disfavour have increased, with both our criteria for market perception now showing significantly negative results. It appears that the hostile reaction of investors persisted and even intensified.

\section{Discussion of the results}

Our results are summarized in Table 4.

In none of the categories related to management policy or structure has there been lasting change. Moreover, the reaction of the market has been hostile, even though investors as a class might be expected to approve of an activist hedge fund intervention as a route to increased shareholder returns, and indeed probably would do so in the USA. We now consider why these results for Japan appear broadly to contradict those for the USA.

We are looking here at a transnational phenomenon, insofar as the practice of aggressive shareholder activism by professionally managed funds was refined in one national market and transferred to another. There are different and often contradictory ways to see this kind of situation. Hansmann and Kraakman (2001), as we have seen, foretold the convergence of international corporate governance practices on the shareholder value principle developed in the USA. In turn, this might imply that activism designed to exploit US corporate governance practices should prove equally effective elsewhere. Non-resident portfolio investors in Japan, often from the USA or the UK, held around $18 \%$ of the Tokyo and Osaka markets by 2000 (National Stock Exchanges, 2004), potentially creating allies for the activists; Ahmadjian, while drawing attention to the many possible outcomes that exist, saw foreign investors as a potential driver of change in Japanese corporate governance, perhaps in the direction of US practices (Ahmadjian, 2007, p. 144-147). On the other hand, diversity still persists in corporate governance around the world and Aguilera and Jackson note the diversity of interrelated institutions that underpin this variety and the lack of homogeneity among such key 
shareholders as pension funds and insurance companies when they are located in different national contexts (Aguilera and Jackson, 2003, p. 447; 2010, pp. 530-2). The varieties of capitalism viewpoint, with its emphasis on institutional similarities and differences (Hall and Soskice, 2001), captures the challenge faced by activist funds in Japan: would their quest for shareholder value find purchase in the institutional environment of Japan, which since the $1950 \mathrm{~s}$ has displayed many of the characteristics associated with what Hall and Soskice (2001) call a 'coordinated market economy' or 'CME'? 'Important issues in the debate are how tightly coupled national institutional configurations are and how much space they leave for fundamental change, for example for convergence between previously different varieties of a capitalist market economy' (Streeck and Yamamura, 2003, p. 2). The varieties of capitalism approach has been criticized for underestimating diversity (Wood et al, 2014) and it seems too sweeping to attribute the activist hedge funds' disappointments exclusively to Japan's possible status as a particular kind of economy. Looking more specifically at our four chosen categories, we offer explanations below from our earlier summaries of the Japanese historical background and current environment and how they differ from those of the USA.

We conclude, firstly, that these interventions harmed rather than improved management effectiveness. In Japan, there has been no tradition of shareholder value as the main objective of corporate activity since the 1930s and boards have become accustomed to a high degree of autonomy. In principle, shareholder pressure may have positive effects where it remedies genuine inefficiencies; our evidence suggests that in the Japanese context it confused and diverted management whose main focus had hitherto been on the business itself. The impact of activism in the Japanese context was further complicated by the decision of funds in the earlier and more successful interventions to press for release of accumulated cash; simply stripping cash from a business does not improve management efficiency.

Management's conscious financial strategy, demonstrated by its decisions on leverage, payout, investment and labour relations showed no change, with management policies in these areas reverting to those of their peers by year three. The US experience suggests that financial strategy is an area where activist hedge funds can add lasting value. However, in Japan, increased leverage, higher payouts, and reduced investment are generally seen as pernicious because they undermine the future financial security of the business and reduce 'corporate value'. We see no signs that hedge fund activists were drawn to these target companies because their labour productivity or wage intensity was out of line with their peers, and these interventions do not appear to have generated any change in the way that the labour forces of the target companies were remunerated or in their productivity.

We now look at market perceptions of this situation, as demonstrated by share prices and values of Tobin's Q. In the USA, Brav et al. (2008) point to evidence of the positive market perception that hedge fund activism generates and Bebchuk et al. (2015) find that this situation endures for at least three years after an intervention. However, we do not find that pattern replicated in Japan. Despite the strong presence of foreign investors in the Japanese market it is rare for them to hold a majority. This is true even among the larger, more international companies where they are more concentrated; their presence is less at the smaller listed companies that we found typically to be targeted by activist hedge funds in 2007 . Major Japanese investors often have genuine portfolio interests but there is often a businesslinked interest too, which causes shareholders to value the ability of the business to trade over its ability to render immediate returns, leading them to reject developments that 
threaten to undermine stability. Additionally, most Japanese investors tolerate great management autonomy up to the point that managers prove themselves clearly inadequate. Activist hedge fund interventions that destabilize the board's control and perhaps raise doubts about its competence (however much local investors may have rallied around to support it against the activists earlier) may therefore encourage the market to perceive targeted companies less favourably.

The global financial crisis from 2007 roughly coincided with the full period of our threeyear study. Brav et al. (2008)'s data finish well before this and even Bebchuk et al. (2015)'s more recent study stops at 2007, so both predate the crisis (although the latter study uses share data up to 2012). The period 2007-10 was a period when financial capitalism was questioned widely and in Japan many saw the crisis both as vindication of more conservative ways of running a business and as proof that hedge fund activism had sought to change companies for the worse. As a director of one targeted company in Japan observed to us in early 2009, 'Now we feel again that what we were saying all along was right'. In such a situation, it is quite plausible that management should revert to more trusted ways. In the same way, it seems plausible that investors should become wary of companies whose boards might have been tainted by shareholder value ideas or whose cash reserves might have been depleted in the ultimately unrealized cause of promoting shareholder primacy. Even in the USA, hedge fund activism became less visible in 2008 and 2009 as the investors who underpinned the funds withdrew their cash; a report from J.P. Morgan, describing the recovery of activism there in 2010, claims that outflows from activists' funds in 2008 and 2009 equalled the inflows of the previous four years (J.P. Morgan, 2010). It could therefore be argued that without the global financial crisis, activist hedge funds might have achieved continuing success in Japan and brought about enduring changes in Japanese corporate governance. In refutation of this, we cite the visceral reaction of the courts to Steel Partners' attempts to overturn Bull Dog Sauce's dilutive counter-measures when they sought to acquire the company in mid-2007: 'A joint-stock company is in theory a for-profit organization that maximizes its corporate value and pays it out as dividends to shareholders. But, at the same time, a company cannot earn its profit without associating with employees, suppliers and consumers. Thus, it can be said that a company is a social entity. Therefore, it must consider its relationships with stakeholders to enhance its corporate value. The idea that it is enough for a company exclusively to consider shareholder value is too limited. If an abusive acquirer seeking only self-interest controls the management of a company, corporate and shareholder value will be harmed' (Tokyo High Court, 2007). There were clearly bigger problems facing aggressive activist hedge funds in Japan than just a temporary shortage of investment cash: the principle of managing a company primarily for the benefit of shareholders was simply not acceptable to public opinion.

A series of developments in Japanese corporate governance regulation since 2014 has seen the introduction of a Stewardship Code and a Corporate Governance Code, together with other reports and continuing committees. The declared objective is to foster economic recovery, but the mechanisms employed - the Stewardship Code which seeks to co-opt investors into the corporate governance debate and the Corporate Governance Code which seeks to promote the OECD's view of governance priorities such as transparency and overview - echo many innovations publically promoted by the activist hedge funds until 2007. This is very much an official attempt to convince managers that their existing practices, in some respects, are no longer 'best practice' (Lane and Wood, 2009, p. 536). It is 
tempting to see these developments as a vindication of the activists' position but the essential element of returning cash to shareholders as a priority is absent. According to an IMF paper from 2014, 'Japan's excessive corporate savings' are still holding back growth (Aoyagi and Ganelli, 2014).

The future trajectory of Japanese corporate governance is therefore still unclear but it is worth considering developments in two other national markets, often compared to Japan as fellow CMEs: Korea and Germany. Korea is especially interesting because it shares a legal system whose historical origins and current form are very close to that of Japan. It deviates from Japan in its preponderance of founding families who control large groups through networks of affiliates but its focus on corporate value is, if anything, even more extreme. The conclusion of a study on attempts to reform corporate governance at Samsung Electronics ('SEC'), possibly Korea's most influential and successful company, was that 'despite its attempts, the overall state of mind of companies such as SEC is to consider requests for improved corporate governance and the demands of minority shareholders as quarrelsome interference' (Jang and Kim, 2002, pp. 95, 98, 103). The experience of the activist Elliott Management in 2015, when it failed to block a reorganization within the SEC group that, in its opinion, disadvantaged minority shareholders, only served to reinforce this view (see, for example, FINalternatives, 2015). The Korean situation is complicated by the influence of founding families and their outward indifference to conflicts of interest.

In Germany, where a growing incidence of hedge fund activism can also be observed, Haberly notes the replacement of traditional patient capital from financial institutions with inflows from sovereign wealth funds at several major German companies after the global financial crisis. In his view, the essential identity of the German model as a CME-type economy has been retained, and has in some ways even been underpinned by this new form of support (Haberly, 2014). Fitchner (2015), similarly, points to the complexity of hedge fund interventions in Germany. As in Japan, there has been a decline in blockholdings of the kind which protected managers in the past from external financial pressures, and an increase in the number of activist hedge fund interventions, although numbers remain very small when compared to the picture in the USA. Fitchner's case studies show that in firms where blockholdings remain, incumbent managers are generally able to fend off hedge fund influence. However, the emerging pattern is not one of simple resistance to activism: in some cases, listed companies have used activist interventions to boost their share price prior to a sale of holdings. At the same time, some activist funds have been prepared to make long-term commitments to the companies they invest in, in effect adapting their strategies to the German context of 'patient capital'.

Both the apparently unresponsive Korean and the apparently more flexible German attitudes to activism can be interpreted as signs that prioritization by management of corporate value at the expense of general shareholder value, once established, does not change easily. Japan's current attempts to promote change may have relevance to both these markets in the future.

\section{Conclusion}

It has recently been argued that 'shareholder activism has gone global' (Becht et al., 2015, p. 1), but a close study of the experience of hedge fund activism in one the world's largest and most enduringly successful market economies, Japan, suggests otherwise. Hedge fund 
activism appears to have produced outcomes in Japan that were very different from the outcomes reportedly achieved in the USA. During the 3 years after hedge fund interventions, the boards of the targeted companies in our sample did not generally become more efficient at delivering profits and neither, after some initial variation in year one, did their financial strategy ultimately deviate from that of their peer groups. Nor did the balance of their labour management, as reflected in productivity and wages, change at all. Perhaps most surprisingly, given the activists' public stance as promoters of shareholder interests, investors in the stock markets did not rate the companies that had been targeted any more highly, as the US experience had suggested they might, and indeed appeared to consider them less valuable than peer companies where no intervention had occurred.

The Japanese situation is clearly different from that of the USA. The shareholder primacy model of corporate governance that underlies so much of hedge fund activism depends on local institutions in order to function consistently and to achieve more lasting results than simply one-off payments. There were other factors at work in Japan, such as the broad toleration of managerial autonomy, but the lack of general acceptance of the shareholder primacy model, as demonstrated by the Bull-Dog Sauce judgment, was the main impediment to the funds' success and demonstrates the need to view Japanese corporate governance as a set of practices embedded in the Japanese business system (Yoshikawa and McGuire, 2008, p. 6). Just as international business studies observe the concept of 'institutional distance' as an impediment to seamless implementation of home country concepts by multinational enterprises (Jackson and Deeg, 2008, p. 543), so there appears to be a similar institutional distance in the practice of corporate governance which accounts for its continuing global diversity. Research from Korea and Germany implies that a corporate value focus does not change easily.

The global financial crisis undoubtedly worked against the interests of the activist hedge funds in Japan from 2008 by reducing their funding and discrediting the idea that companies should operate with minimal reserves while maximizing distributions. However, the strength of opposition to the funds' attempts to strip out more cash before the crisis suggests that antipathy to shareholder value ideas was much more fundamental in Japan than something simply occasioned by the crisis. Whereas American researchers in 2015 could still claim that interventions generated lasting improvements in targeted companies in the USA, our research shows no such signs in Japan.

Extrapolating from our quantitative results, we suggest the following explanation of this situation. If corporate governance is a local phenomenon, embedded in its historical context, as seems to be the case in Japan, then only convergence of historical experience is likely to generate similarity of corporate governance practice. Changes in Japan since 2014 may point the way to an acceptance of different interpretations of corporate purpose. It is too early to tell if Japan will ever embrace shareholder value fully, although change can come suddenly after a long delay, as Mahoney and Thelen observe (Mahoney and Thelen, 2010, p. 31). Nevertheless, corporate governance arises from its environment and particular forms of it cannot easily be imposed at short notice from above, mainly because key receptors for the behaviour they require are unlikely to be present in a different environment. As Culpepper observes in the particular context of corporate acquisitions: 'Some regimes of corporate control treat companies as mere commodities, free to be bought and sold at will by owners in search of the highest rate of return on their investment. Others, in contrast, view the company as a place where many important political and distributive compromises of capitalist democracy are 
struck.... These differences are fundamental to the distinction between different varieties of capitalism' (Culpepper, 2011, p. 177). This situation does not preclude change but it means that change is most likely to be driven not by a dispassionate assessment of the attractions of any particular model of corporate governance but by the accumulated weight of institutional changes in any given national environment (Filatotchev et al, 2013). The impediment faced by the activist hedge funds observed in this study was that they were attempting to subvert institutionalized patterns of behaviour in the short term, relying on their preferred logical arguments and ignoring the fact that these ran counter to the weight of common practice. Without a general acceptance that shareholder value was the prime corporate objective, their attempts to extract value were seen simply as extortion.

Our findings have implications for the wider literature on the impact of different types of ownership (passive and active, foreign and domestic) on corporate governance structures and outcomes. Ahmadjian's research on the impact of foreign institutional ownership on Japanese companies (Ahmadjian, 2007) suggests that it often goes hand in hand with increases in downsizing and restructuring, factors which have tended, in turn, to undermine the institution of lifetime employment. Similarly, Guery et al. (2017) find that the involvement of foreign investors in private equity-led buyouts in France makes it more likely that redundancies and a reduction in employment will result. Our results, however, suggest that in the Japanese context, hedge fund interventions, which have been overwhelmingly foreign in origin, have not led to significant changes in domestic firms' strategies to the management of labour. It would seem that Japanese firms have been particularly resistant to the confrontational style of corporate governance which the activist funds pursued. A potentially fruitful avenue for work would to compare and contrast outcomes from hedge fund activism with those from other so-called 'alternative investments', including sovereign wealth funds and private equity (Applebaum and Batt, 2014; Goergen et al., 2014), in Japan and elsewhere.

\section{Acknowledgements}

We thank the editors and three anonymous referees for their comments. We also gratefully acknowledge funding from the ESRC's Rising Powers and Interdependent Futures Research Programme, Project 'Law, Development and Finance in Rising Powers', Grant No. ES/J012491/1, and the Omron Fund at Doshisha University, Kyoto.

\section{References}

Aguilera, R. V., and Jackson, G. (2003) 'The Cross-National Diversity of Corporate Governance: Dimensions and Determinants', Academy of Management Review, 28, 447-465.

Aguilera, R. V., and Jackson, G. (2010) 'Comparative and International Corporate Governance', The Academy of Management Annals, 4, 485-556

Ahmadjian, C. L., and Robbins, P. (2001) 'Safety in Numbers? Downsizing and the Deinstitutionalisation of Permanent Employment in Japan', Administrative Science Quarterly, 46, 622-654

Ahmadjian, C. L., and Robbins, G. E. (2005) 'A Clash of Capitalisms: Foreign Shareholders and Corporate Restructuring in 1990s Japan’, American Sociological Review, 70, 451-471.

Ahmadjian, C. L. (2007) 'Foreign Investors and Corporate Governance in Japan', In Aoki, M., Jackson, G. and Miyajima, H. (eds), Corporate Governance in Japan: Institutional Change and Organizational Diversity, New York, Oxford University Press, pp. 125-150. 
Aoyagi, C., and Ganelli, G. (2014) 'Unstash the Cash! Corporate Governance Reform in Japan', IMF Working Paper 14/140, accessed at https:// www. imf. org/ external/ pubs/ ft/ wp/ 2014/ wp14140. pdf on 12 December 2016.

Applebaum, E., and Batt, R. (2014) Private Equity at Work: When Wall Street Manages Main Street, New York, Russell Sage Foundation.

Bebchuk, L. A., Brav, A., and Jiang, W. (2015) 'The Long-Term Effects of Hedge Fund Activism', Columbia Law Review, 115, 1085-1155.

Becht, M., Franks, J., Grant, J., and Wagner, H. (2015) 'The returns to hedge fund activism: an international study' ECGI Finance Working Paper No. 402/2014, accessed at SSRN: https:// papers. ssrn. com/sol3/ papers. cfm? abstract_id=2376271 on 08 August 2017.

Berle, A. A., and Means, G. C. (1932) The Modern Corporation and Private Property, New Brunswick, NJ, Transaction Publishers.

Blair, M., and Stout, L. A. (1999) 'A Team Production Theory of Corporate Law', Virginia Law Review, 85, 248-328

Bratton, W. W. (2007) 'Hedge Funds and Governance Targets', The Georgetown Law Journal, 95, 1375-1433.

Brav, A., Jiang, W., and Kim, H. (2015) 'The Real Effects of Hedge Fund Activism: Productivity, Asset Allocation, and Labor Outcomes', The Review of Financial Studies, 28, 2723-2769.

Brav, A. et al. (2008) 'Hedge Fund Activism, Corporate Governance, and Firm Performance', The Journal of Finance, 63, 1729-1775

Buchanan, J., Chai, D. H., and Deakin, S. (2012) Hedge Fund Activism in Japan: The Limits of Shareholder Primacy, Cambridge, Cambridge University Press.

Cadbury, A. (2002) Corporate Governance and Chairmanship: A Personal View, Oxford, Oxford University Press.

Conference Board. (2008) The 2008 Institutional Investment Report: Trends in Institutional Investor Assets and Equity Ownership of U.S. Corporations, New York, The Conference Board.

Culpepper, P. D. (2011) Quiet Politics and Business Power: Corporate Control in Europe and Japan Cambridge, Cambridge University Press.

Davis, J. H., Schoorman, D. F., and Donaldson, L. (1997) 'Toward a Stewardship Theory of Management', Academy of Management Review, 22, 20-47.

Dore, R. (2000) Stock Market Capitalism: Welfare Capitalism: Japan and Germany versus the Anglo-Saxons, Oxford, Oxford University Press.

Fichtner, J. (2015) 'Rhenish Capitalism Meets Activist Hedge Funds: Blockholders and the Impact of Impatient Capital', Competition and Change, 19, 336-352

Filatotchev, I., Jackson, G., and Nakajima, C. (2013) 'Corporate Governance and National Institutions: A Review and Emerging Research Agenda', Asia Pacific Journal of Management, 30, 965-986

FINalternatives (2015) accessed at http:// www. finalternatives. com/ node/ 31564 on 08 August 2017

Fitchner, J. (2015) 'Rhenish Capitalism Meets Activist Hedge Funds: Blockholders and the Impact of Impatient Capital', Competition and Change, 19: 336-352

Guery, L. et al. (2017) 'The Impact of Private Equity on Employment: The Consequences of Fund Country of Origin - New Evidence from France', Industrial Relations: A Journal of Economy and Society, 56, 723-750

FT (2008) 'TCI Sells Out of J-Power at a Loss', Financial Times, London, accessed at https:// www. ft. com/ content/ f2028abe- a745-11dd- 865e- 000077b07658? mhq5j=e1on 08 August 2017.

Goergen, M., O'Sullivan, N., and Wood, G. (2014) 'The Consequences of Private Equity Investments for Employees: New Evidence on the Impact on Wages, Employment and Productivity', Human Resource Management Journal, 24, 145-158 
Gospel, H. et al. (2011) 'New Investment Funds, Restructuring, and Labor Outcomes: A European Perspective', Corporate Governance: An International Review, 19, 276-289

Gordon, A. (1998) The Wages of Affluence: Labor and Management in Postwar Japan, Cambridge, MA, Harvard University Press.

Haberly, D. (2014) 'White Knights from the Gulf: Sovereign Wealth Fund Investment and the Evolution of German Industrial Finance', Economic Geography, 90, 293-320

Hall, P. A. and Soskice, D. (eds) (2001) Varieties of Capitalism - the Institutional Foundations of Comparative Advantage, Oxford, Oxford University Press.

Hansmann, H., and Kraakman, R. H. (2001) 'The End of History for Corporate Law', The Georgetown Law Journal, 89, 439-468.

Jackson, G. (2003) 'Corporate Governance in Germany and Japan: Liberalization Pressures and Responses during the 1990s', In Yamamura K. and Streeck W. (eds) The End of Diversity? Prospects for German and Japanese Capitalism, Ithaca and London, Cornell University Press, pp. 261-305.

Jackson, G., and Deeg, R. (2008) 'Comparing Capitalisms: Understanding Institutional Diversity and Its Implications for International Business', Journal of International Business Studies, 39, 540-561

Jang, H., and Kim, J. (2002) 'Nascent Stages of Corporate Governance in an Emerging Market: Regulatory Change, Shareholder Activism and Samsung Electronics', Corporate Governance: An International Review, 10, 94-105

Jensen, M. C. (1986) 'Agency Costs of Free Cash Flow, Corporate Finance, and Takeovers', American Economic Review, 76, 323-329.

Jensen, M. C., and Meckling, W. H. (1976) 'Theory of the Firm: Managerial Behavior, Agency Costs and Capital Structure', Journal of Financial Economics, 3, 305-360

Kay, J., and Silberston, A. (1995) 'Corporate Governance', National Institute Economic Review, $153,84-95$

Kellard, N. et al. (2017) 'Close Communications: Hedge Funds, Brokers and the Emergence of Herding’, British Journal of Management, 28, 84-101

Klein, A., and Zur, E. (2009) 'Entrepreneurial Shareholder Activism: Hedge Funds and Other Private Investors', The Journal of Finance, 64, 187-229

Klein, A., and Zur, E. (2011) 'The Impact of Hedge Fund Activism on the Target Firm's Existing Bondholders', Review of Financial Studies, 24, 1735-1771

Lane, C., and Wood, G. (2009) 'Capitalist Diversity and Diversity within Capitalism', Economy and Society, 38, 531-551

Lechevalier, S. (2014) 'Introduction: Seven Japanese Lessons on the Diversity of Capitalism and its Future', In Lechevalier S. (ed.), The Great Transformation of Japanese Capitalism, Abingdon, Routledge, pp. 1-25.

Li, Y., and Xu, J. (2009) 'Hedge Fund Activism and Bank Loan Contracting', accessed at https:// papers. ssrn. com/sol3/ papers. cfm? abstract_id=1573217 on 08 August 2017.

Lipton, M. (2013) 'Important Questions about Activist Hedge Funds', Harvard Law School Forum on Corporate Governance and Financial Regulation, 9 March 2013, accessed at https:// corpgov. law. harvard.edu/2013/03/09/important-questions-about-activist-hedge-funds/ on 08 August 2017.

Macey, J. (2008) Corporate Governance: Promises Kept, Promises Broken, Princeton, NJ, Princeton University Press.

Mahoney, J., and Thelen, K. (2010) 'A Theory of Gradual Institutional Change', In Mahoney and Thelen (eds), Explaining Institutional Change: Ambiguity, Agency and Power, New York, Cambridge University Press, pp. 1-37.

MIC (2013) 労動力調査 長期時系列データ (Labour Force Survey, Long-term Time Series Data), Tokyo, 総務省、統計局 (Ministry of Internal Affairs and Communications, Statistics Bureau). 
Mitarai, F., and Niwa, U. (2006) 会社は誰のために (Who is the company for?) Tokyo, 文藝春秋 (Bungei Shunjū).

Miyajima, H. (2017) 企業統治と成長戦略 (Corporate Governance and Growth Strategy) (Tokyo: Tōyō Keizai Shinpōsha).

Morgan J. P., (2010) 'Hedge Fund Activists 2.0: they are Back!' (Report by Zenner, M., Gosebruch, H., and Berkovitz, T.) accessed at https:// www. jpmorgan. com/ tss/ General/ Hedge_Fund_Activists_2_0_ They_are_back/ 1279234044476 on 08 August 2017.

National Stock Exchanges (2004) 平成15年度株式分布状況 調 査の結果につういて (Results of shareholder distribution survey for 2003), 全国証券取引所 (National Stock Exchanges).

OECD (2009) 'Institutional investors' assets and liabilities', accessed at http://www.oecd-ilibrary. org/finance-and-investment/data/oecd-institutional-investors-statistics/institutional-investorsassets-and-liabilities_c4292928-en; jsessionid=2ongr4197cfc0.x-oecd-live-02 on 08 August 2017.

Preqin (2014) Preqin Special Report: Activist Hedge Funds, accessed at https://www.google.co.uk/ search? $\quad \mathrm{q}=$ Preqin + special + report $\% 3 \mathrm{~A}+$ activist + hedge + fundsandie $=$ utf- 8 andoe $=$ utf- 8 and client=firefox-bandgfe_rd=crandei=vpqJWZeHBqXVXvSGgfAL on 08 August 2017.

Reuters (2009) 'Steel Partners Cuts Stakes in Japan Firms by \$1.7 Billion', accessed at http://uk.reu ters.com/article/us-steel-partners-japan-idUKTRE50F2FU20090116 on 08 August 2017.

Sako, M. (2005) 'Does Embeddedness Imply Limits to within-Country Diversity?', British Journal of Industrial Relations, 43, 585-592.

Streeck, W., and Yamamura, K. (2003) 'Introduction: Convergence or Diversity? Stability and Change in German and Japanese Capitalism', In Yamamura K. and Streeck W. (eds), The End of Diversity? Prospects for German and Japanese Capitalism, Ithaca and London, Cornell University Press, pp. 1-50.

Strine, L. (2016) 'Corporate Power Is Corporate Purpose I: Lessons from My Hometown', Institute for Law and Economics Research Paper, 16-34 accessed at https://papers.ssrn.com/ sol3/papers.cfm? abstract_id=2906875 on 08 August 2017.

Sundaram, A. K., and Inkpen, A. C. (2004) 'The Corporate Objective Revisited', Organization Science, 15, 350-363.

Tachibanaki, T. (ed.) (1998) Who Runs Japanese Business? Cheltenham, Edward Elgar Publishing Limited.

Tiberghien, Y. (2014). 'Thirty Years of Neo-Liberal Reforms in Japan', In Lechevalier S. (ed.), The Great Transformation of Japanese Capitalism, Abingdon, Routledge, pp. 26-55.

Tokyo High Court. (2007) 'Appeal Regarding Dismissal Decision on Application for Provisional Disposition to Prohibit Decision of Shareholders' Meeting etc. Ref. 2007 (ra) no.917', Tokyo, Tokyo High Court, 09 July 2007.

Wood, G., Dibben, P., and Ogden, S. (2014) 'Comparative Capitalism without Capitalism, and Production without Workers: The Limits and Possibilities of Contemporary Institutional Analysis', International Journal of Management Reviews, 16, 384-396.

Yoshikawa, T., and McGuire, J. (2008) 'Change and Continuity in Japanese Corporate Governance', Asia Pacific Journal of Management, 25, 5-24. 


\section{Appendix 1}

List of 17 funds associated with target companies in sample

\begin{tabular}{llr}
\hline Investor Name & Country & Targets \\
\hline Blue Sky Capital Management Pty. Ltd. & Australia & 3 \\
Dalton Investments, LLC & USA & 6 \\
Elmwood Advisors Pte. Ltd. & Singapore & 1 \\
Gandhara Advisors Asia Limited & Hong Kong & 2 \\
Halberdier Capital Management & Singapore & 2 \\
HBK Investments, LP & USA & 1 \\
Ichigo Asset Management, Ltd. & Japan & 7 \\
Indus Capital Partners, LLC & USA & 3 \\
Liberty Square Asset Management, LLC & USA & 11 \\
Och-Ziff Capital Management, LLC & USA & 2 \\
Perry Capital & USA & 1 \\
Silchester International Investors & UK & 1 \\
Steel Partners, LLC (JV with Liberty Square) & USA & 29 \\
Symphony Financial Partners Co., Ltd. & Japan & 19 \\
The Children's Investment Fund Management LLP & UK & 1 \\
Tower Investment Management Co., Ltd. & Japan & 29 \\
Wesley Capital Management, LLC & USA & 1 \\
Total (including two targets where two funds were present): & & 119 \\
Total (adjusted for multiple fund presence): & & 117 \\
\hline
\end{tabular}

\section{Appendix 2}

Variable definition

\begin{tabular}{|c|c|}
\hline Variable & Definition \\
\hline \multicolumn{2}{|l|}{ Managerial effectiveness } \\
\hline Return on assets & Ratio of total net income to total assets \\
\hline Return on equity & Ratio of total net income to shareholder's equity \\
\hline \multicolumn{2}{|l|}{ Managerial decisions } \\
\hline Dividend/assets & Ratio of total dividend payments to total assets \\
\hline Leverage & Book leverage ratio defined as debt/(debt + book value of equity \\
\hline Cash/assets & Ratio of total cash to total assets \\
\hline Capital Expenditures/assets & Ratio of total capital expenditure spending to total assets \\
\hline \multicolumn{2}{|l|}{ Labour management } \\
\hline Labour productivity & Ratio of total sales to employee numbers (in million yen) \\
\hline Wage intensity & Ratio of expenditure on wages to total sales \\
\hline Average age of workforce & Average age of employees \\
\hline \multicolumn{2}{|l|}{ Market perception } \\
\hline Ln(Market Cap) & Natural logarithm of market capitalization in billions of yen \\
\hline Tobin's Q & $\begin{array}{l}\text { Tobin's Q defined as (equity market value }+ \text { book value of total } \\
\text { liabilities excluding shareholders' equity)/(equity book value }+ \\
\text { book value of total liabilities excluding shareholders' equity). }\end{array}$ \\
\hline
\end{tabular}

